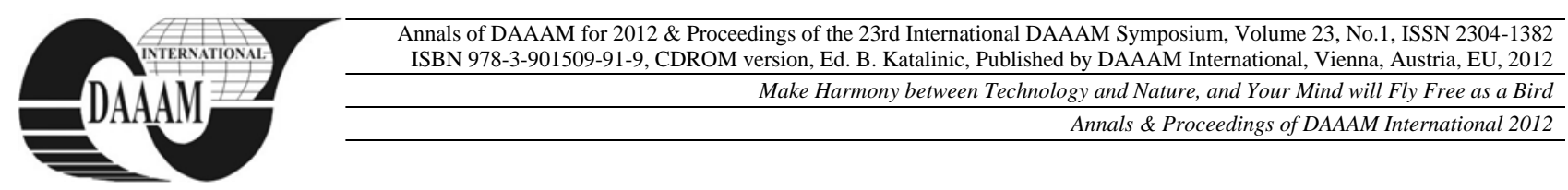

\title{
BUSINESS RISKS BETWEEN EMERGING AND MATURE ECONOMIES
}

\author{
DANCIULESCU, A[lexandra] I[rina]
}

\begin{abstract}
The main objective of this paper is to show how business risk influences economy, especially nowadays, in the context of the economic crisis. The paper presents how the emerging and mature economies are influenced by risk. In addition, it points out the risks emerging from the crisis. Despite scattered signs of improvement, the world economic situation and prospects continue to be challenging. An escalation of the crisis would likely be associated with severe turmoil on financial markets and a sharp rise in global risk aversion, leading to a contraction of economic activity in developed countries, which would spill over to developing countries and economies in transition. A further sharp rise in global energy prices may also stifle global growth. National and international concerted policies should be enacted on multiple fronts in order to break out of, rising unemployment, fiscal austerity and financial sector fragility in developed economies. These policies need to be better coordinated across the major economies and concerted with continued expansionary monetary policies in developed countries, and accompanied by accelerated financial sector reforms and enhanced development assistance for low-income countries.

Keywords: Risk, emerging economies, mature economies, financial crisis
\end{abstract}

\section{INTRODUCTION}

In current language risk, management is associated with risk control or vice versa. In most literature, the two concepts have similar but not identical definitions. Risk management applied formally became consistent only in $\mathrm{XX}^{\text {th }}$ century thanks to Henry Fayol, one of the first men who put the basis for Business Management [1].

Risk management is actually the name given to logical and systemic methods of identification, analysis, treatment and monitoring risks involved in any activity or process.

The definition of risk management that was and still is, would be the following:

- firstly, risk management may be associated with the process of protecting a person or organization, from the point of view of their assets and income;

- Secondly, the definition refers to the business management function, using a scientific approach to deal with risk [1].

Risk management is defined by ISO30001 (Risk Management ISO Standard) as an uncertainty effects over objectives no matter if they are positive or negative. In order to manage risk, strategies include transferring the risk to a third party, avoiding risk, decreasing the negative or probable effect of the risk, or even accepting some potential or actual consequences of a certain risk.

In the context of market expansion and consequences deriving from this process, we need to identify specific elements of business risk that affect organizations and by default economies.

Although risk management is still under evaluated, there are opportunities in the business environment that could be capitalized by adapting the firm's mission and management in order to concur with requirements made by business globalization and firm internationalization [2].

The lack of information, the difficulties of research in this field represent the main cause of an insufficient development in risk management.

This paper wants to identify the similarities and differences in development between emerging and mature economies, for better business risk management [2].

\section{EMERGING ECONOMIES}

The most adequate "definition" of an emerging economy would be the one that identifies an economy about to be structured economically and financially; this structuring allows the particular economy to follow a trajectory that insures internal sustainability, on one hand, and protects from external economic shocks, on the other.

Thus, emerging economies are economies with a very important role on the international market that can become main actors but are not yet at that level. Emerging economies exist in less developed countries, in comparison to United States or Europe; a major example would be Brazil, Russia, India and China.

The financial collapse in the United States, generated a recession that hit the West as well as BRIC economies (Brazil, Russia, India, China), thus decreasing global economic growth [3].

Brazil is considered one of the four emerging economic powers that will dominate 2050. Brazil had a very important road to walk from the transition to democracy 
from late ' 80 's and after the economic crisis of ' 90 and '94.

The growth of the Russian power in relation to the European Union, translates through the fact that the community is dependent on the Russian gas in proportion of $40 \%$ [3]. Russia has the largest territory of the world, the biggest natural resources of gas from the world (plus oil and minerals). Oil and gas shipments have been $67 \%$ of all Russian exports.

India's growth is due to the development of the service industry, which according to New Delhi Minister of Statistics, makes over $50 \%$ contribution to India's GDP [3].

The information provided by this institution shows that the other two major contributors to Sate Budget are manufacturing $(26,2 \%)$ and agricultural ( $19,7 \%)$ sector. The same as Russia and China, India has several geopolitical advantages: a wide territory (the $7^{\text {th }}$ in the world) and a big population 1 billion, second place in the world, after China). Although India is growing, this image is shadowed by the poverty of the population in the countryside and the fact that most Indians work in agriculture [3].

When IMF refused to loan Angola cash, China saw an opportunity and helped Angola without any preconditions. Today, Angola exports more oil in China, than Saudi Arabia. Over the years, China becomes an important geopolitical actor not only in Africa, South America, Middle East, but also in Central Asia. To this regard was created the Shanghai Cooperation Organization formed by 6 States (China, Russia, Kazakhstan, Kirghizstan, Tajikistan and Uzbekistan), that seems to become more of a political- military unit that wants to counterbalance the influence of the United States in Central Asia [3].

U.S. National Intelligence Council predicts that in time, government investment funds, controlled by BRIC countries, will grow to pump in to emerging economies more money than IMF and The World Bank together, which might lead to change in structure of alliances in the international relations space. We have to bear in mind that China's economic growth depends on the Western markets [3].

\section{MATURE ECONOMIES}

As a general characterization, developed economies have the following specifics:

- Countries with market economy, even though some claim the existence of post capitalism after the World War 2. Still, these economies have proven their viability and efficiency, based on private property;

- As State forms, most of them are republics, but there are some monarchies ( Great Britain, Belgium, Holland, Norway, Denmark, Sweden);

- They have increased economic efficiency, found in high productivity of labor, in GDP, increased consumption/inhabitant. High efficiency can be explained through managerial revolution; their economic advance in comparison with other States, can be attributed to an extensive development of inputs, based mostly on information and technology;

- They have a diversified economical structure; the most representative sectors are industry and services, even the main sector is highly industrialized;

- The literacy rate is $100 \%$, thus influencing human development;

- Their population have access to health services and insurance services;

- They dominate global economy through international commerce, foreign investments, technology [4]. For example, these countries import goods and export low value-added products with high added value;

- They represent the mother land for all the major transnationals;

- Have the powerful currencies, some of them being reserve currencies for other countries of the world[4];

- The most representative financial markets are found in developed countries; they have the most significant achievements in research-development field.

We have to notice that these characteristics are not generally applicable for all countries.

\begin{tabular}{|c|c|c|c|c|c|}
\hline - Annual growth in real terms, $\%-$ & 2009 & 2010 & $\begin{array}{c}2011 \\
\text { estimation }\end{array}$ & $\begin{array}{c}2012 \\
\text { prognosis }\end{array}$ & 2013 \\
prognosis & 3,1 \\
\hline G.D.P. GLOBAL, from which: & $-2,3$ & 4,1 & 2,7 & 1,3 & 1,9 \\
\hline 1. OCDE (34 countries), from which: & $-3,7$ & 2,8 & 1,4 & $-0,3$ & 1,1 \\
\hline - Euro Zone (17 countries) & $-4,2$ & 1,7 & 1,6 & 2,2 & 2,4 \\
\hline - United States & $-3,5$ & 3,0 & 1,7 & 1,9 & 1,6 \\
\hline
\end{tabular}

Fig. 1. The global economy and international growth evolution during 2009-2013 Source: [5] 
There are some new countries that just entered the developed countries group, that do not meet these requirements, thus contesting their status of developed countries [4].

According to the traditional World Bank Report: "Global Economic Prospects"( makes prognosis for 2012 global economy and commerce ), developed countries are supposed to have a rhythm of economic increase of only $1.4 \%$ in 2012 and $2.0 \%$ in 2013 not $2.7 \%$ and $2.6 \%$ the estimated numbers from June 2011 for the respective years [5]. The Euro Zone Countries are supposed to register a negative rhythm of $0,3 \%$ in 2012 (towards a GDP growth of $2.1 \%$ previously foreseen) and come out of recession in 2013, $2.0 \%$ being the foreseen rhythm. United States and Japan are the only developed countries that will register high economic increases in 2012 towards 2011. World Bank experts predict a rhythm increase of $2.2 \%$ for United States (1, 75 in 2011) and $1.9 \%$ for Japan $(-0.9 \%$ in 2011) [5].

\section{EXISTENCE OF SUPLIMENTAR RISKS}

"Four years after financial crisis swallowed global economy, the world doesn't seem to close to finding a sustainable economic model, and regulatory structures must approach banks' problems by pushing them to accept their loses, to eliminate loses from their balance sheets and to consolidate assets in order to finance a sustainable economic growth" ( Bank for International Settlements Report, 2012)[6].

"Revitalization of banks and moderating financial industry will end the destructive interaction with the other sectors and will allow the next steps: fiscal consolidation and decreasing leverage ratios in the non financial private sector. Only then we will be able to have a balanced growth", said the chief-economist Stephen Cecchetti at the launching for the annual report of Bank for International Settlements for 2012 [6].

Developed economies are more exposed to risks, especially in Europe, but emerging economies deal with bigger risks, especially those who grew fast through exports to their more developed neighbors."Countries like Russia and India might have considerable problems if their commerce partners register a slow increase, as it is foreseen for 2011-2015", states the report [6].

Jaime Caruana, CEO of BIS (Bank for International Settlements) and former governor of National bank of Spain, warns us that recent aggressiveness of central banks might be creating "unrealistic demands" regarding their power to "resolve fundamental problems", and the expansion of central banks actions would involve risks, according to notes prepared for the annual meeting of BIS [6].

"Monetary policy provides the necessary time for other policies to correct the fundamental problems from balance sheets. Even so, this transition role presents risks and limitations. In the actual circumstances, the benefits of a continuing quantitative relaxation has certain costs", said Caruana [6].

\subsection{Risks brought by central banks}

Jaime Caruana, CEO of BIS and former governor of national bank of Spain, identified three major risks regarding central banks [6]. The first risk comes from the fact that "prolonged monetary stimulation makes fiscal and structural adjustments to seem less urgent", allowing governments and banks to delay certain painful but necessary changes [6].

The second risk comes from low interest rates, that could lead investors and financial institutions to assume greater risks searching for a better return [6]. The last risk could cause central banks to have difficulties in "calibrating and implementing monetary policies that is unavoidably necessary" which might lead to a new bubble of credit or an inflation explosion [6].

"Fiscal adjustment, the repair of banks' balance sheets and other reforms cannot be put off in the hope of better times. Relying only on central bankers but failing to act on other fronts would ultimately damage confidence and increase the risks to macroeconomic and financial stability," said Caruana [6].

Although the stock markets' tendency to exaggerate is well known, now investors' fears seem accurate, taking into consideration that OCDE sees the development of the world's greater economies slowing down. Germany, announced that Junes' exports decreased with $1.2 \%$ to 88.5 billion, after an increase of 4.4\% in May 2012 [6].

Large decreases on stock markets, sustained by an overwhelming pessimism that will persist, could be transmitted in real economy, and could hit the trust of consumers, which will have serious consequences for economies based mostly on consumers expenses, like United States.

\section{HOW DO EMERGING ECONOMIES GROW}

Estimates show that $70 \%$ of world growth over the next few years will come from emerging markets, with China and India accounting for $40 \%$ of that growth [7].

Adjusted for variations in purchasing power parity, the ascent of emerging markets is even more impressive: the International Monetary Fund (IMF) forecasts that the total GDP of emerging markets could overtake that of the developed economies as early as 2014 .

The forecasts suggest that investors will continue to invest in emerging markets for some time to come. The emerging markets already attract almost $50 \%$ of foreign direct investment (FDI) global inflows and account for $25 \%$ of FDI outflows [7].

The brightest spots for FDI continue to be Africa, the Middle East, and Brazil, Russia, India and China (the BRICs), with Asian markets of particular interest at the moment. 
By 2020, the BRICs are expected to account for nearly $50 \%$ of all global GDP growth. Securing a strong base in these countries will be critical for investors seeking growth beyond them [7].

As emerging market countries gain in stature, new companies are taking center stage. The rise of these emerging market leaders will constitute one of the fastest-growing global trends of this decade.

These emerging market companies will continue to be critical competitors in their home markets while increasingly making outbound investments into other emerging and developed economies [7].

Working to serve customers of limited means, the emerging market leaders often produce innovative designs that reduce manufacturing costs and sometimes disrupt entire industries.

As a result, these companies possess a more innovative, entrepreneurial culture and have developed greater flexibility to meet the demands of their local and "bottom-of-the-pyramid" customers [7].

\subsection{Romania}

Although, the European Union is headed to recession, Romania still has chances to expect economic growth by concentrating on development, investments, production and consumption. Poland remains a "book example" by registering economic growth while Europe and the United States fought recession. Romania found itself in the second trimester of this year, between the countries of UE that have not had economic decrease.

According to Eurostat, in the second trimester of 2012, comparing with 2011, GDP decreased with $0.2 \%$ in the Euro Zone and in the entire European Union; but Romanian economy increased with $0.5 \%$ in the same period and it seems that it will keep up increasing throughout this year and 2013[8].

In addition, Romanian economy increased with $0.8 \%$ in the first trimester compared with the same period in 2011.

The evolution of GDP in the second trimester indicates that the economy of the Euro Zone and European Union could go in to recession in the third trimester.

Mario Draghi, the President of Central European Bank said in an interview that , economic indicators still, show a low economic activity for the end of 2012, marked by a high level of uncertainty” and that ,on the short run we should expect Euro Zone economy to recover slowly"'[8].

For 2012, Central European Bank predicts an economic contraction in the Euro Zone, of 0.6\%-0.2\%.

As far is Romania is concerned, International Monetary Fund and Romanian authorities expect an economic growth of approximately $1 \%$ this year, while the most negative estimates decrease to $0.6 \%$, due to agricultural disaster and to the unfriendly foreign environment.
So, according to this facts, Romania is fourth in rank, in the second trimester of this year, after Sweden (1.4\%), Lithuania (1\%), Slovakia $(0.7 \%)$, and before Bulgaria (0.2\% growth) and Czech Republic that registers a contraction of $0.2 \%$ [8].

In addition, the growth of Germany, Europe's biggest economy, decreased to $0.3 \%$ of GDP in the second quarter compared to the first three months of the year, when it was placed at $0.5 \%$, while the French economy stagnated during the analyzed period.

Even the "polish miracle", the only European economy that never entered recession after Lehman Brothers collapsed, lost its intensity, increasing only with $0.4 \%$ in the last three years.

Not only the economic growth places Romania among the leading countries of Europe, but also the government debt, the fourth lowest in the EU as a percentage of GDP after the first three months, 36.3\% and 211 billion lei. Yet, our public debt increased with $5.4 \%$ compared to the same trimester of 2011, being the sixth most rapid rate of growth.

Among other EU countries, the largest share of government debt in GDP was recorded in Greece $(132.4 \%)$, Italy $(123.3 \%)$, Portugal $(111.7 \%)$ and Ireland $(108.5 \%)$, while Estonia (6.6\%), Bulgaria (16.7\%) and Luxembourg $(20.9 \%)$ are the countries with the lowest percentages[8].

As nominal value, Germany has the highest debt of 2.112 billion euros, followed by Italy (1.946 billion euros) and France (1.789 billion euros).

Although, Romanian GDP increased, this performance is not reflected in Romanians way of life. The indicator that states best the economic situation of a country is the power of buying of its inhabitants. In this chapter, Romania is on the second lowest place in the European Union, before Bulgaria, the buying power being $50 \%$ smaller than the EU average.

\section{OPPORTUNITIES FOR IMPROVEMENT}

The classification of the 'BRIC' nations as emerging is outdated; for many corporations, Brazil, Russia, India and China are now considered to be advanced, with Central and Eastern European markets perceived similarly.

At the other end of the spectrum lie the less developed and often more volatile 'frontier markets', such as Iraq, Libya, Syria and most of Sub-Saharan Africa, where operational risk is far greater, and there are more challenging barriers to entry [9]. However, often countries can no longer be categorized as 'emerging' in their entirety, given that the levels of development in most capital cities often exceed those in second and third-tier cities.

For example, remote areas of Canada and Russia, both developed nations, can pose significantly more 
operational challenges than the urban core. Emerging markets can therefore exist within the boundaries of stable countries, meaning that corporate real estate executives must consider sub-market characteristics when developing their location strategies [9].

Corporations are shifting their focus to the world's east and south: for many companies, Asia, Latin America and Africa are the current locations of choice for strategic medium-term expansion [9].

However, the degree of variation and complexity within these broad regions means that a uniform approach is unlikely to be effective. In Asia, for instance, India is regarded as an 'emerged' market for many functions, with future potential focused on places like Vietnam, Thailand and The Philippines [9]. Thus, is very important to continue efforts in order to consolidate fiscal positions and gaining competitivity, leading to a stable economy.

In order to eliminate the economic unbalances, we have to implement certain reforms on goods and services markets, on labor markets and in the financial sector; competitiveness should be intensified through unified market and, of course, income should be adjusted accordingly. These reforms are destined to increase economic growth and to create jobs.

\section{CONCLUSIONS}

Four major weaknesses continue to conspire against robust economic recovery in developed economies, creating a vicious cycle: i) deleveraging by banks, firms and households continues to restrain normal credit flows and consumer and investment demand; ii) unemployment remains high, a condition that is both cause and effect in preventing economic recovery; iii) fiscal austerity responses to rising public debts deter economic growth and make a return to debt sustainability all the more difficult; and iv) bank exposures to sovereign debt perpetuate fragility in the financial sector, which in turn spurs continued deleveraging.

The World Economic Situation and Prospects mid2012 says that to break out of the vicious cycle, more concerted and more coherent efforts on several fronts of national and international policymaking will be needed[10].

First, countries need to shift away from self-defeating fiscal austerity and towards a renewed stimulus, which provides support to weak global demand. Second, fiscal policies need to be redirected to more directly support job creation and green growth[10].

Third, stability of the global monetary and financial system needs to be increased through better-coordinated policies and accelerated financial sector reform. Fourth, policymakers need to ensure that sufficient resources are made available to developing countries, especially those possessing limited fiscal space and facing large development needs [10].
These resources will be needed to accelerate progress towards the achievement of the Millennium Development Goals (MDGs) and for investments in sustainable and resilient growth, especially for the least developed countries [10].

At the current juncture, the euro area crisis remains the biggest threat to global growth in the outlook period. An escalation of the crisis would likely be associated with severe turmoil in financial markets and a sharp rise in global risk aversion, leading to a contraction of economic activity in developed countries at large, which would spill over to developing countries and economies in transition[9]. Although some progress was made in early 2012 in easing financial market tensions, euro area policymakers have so far not addressed the fundamental and closely intertwined issues at the core of the crisis.

They will face major challenges related to the vulnerability of financial institutions and the high level of sovereign debt. Fighting these challenges is complicatedbecause of structural imbalances within the euro area and the lack of growth impulses.

Average unemployment in the region is at its highest level since the common currency was introduced; and many economies face anaemic growth or recessions as firms and households are in a process of deleveraging, while governments pursue contractionary fiscal policies[10].

Despite the recent efforts of the Central European Bank, bank funding markets are far from normal yet: Bank credit risk remains at a high level and investors' confidence in banks is weak as reflected in the low prices of banking shares. Together with persistent high unemployment, the still ongoing deleveraging by households and fiscal austerity measures by Governments is keeping the risk of Europe entering into a downward, deflationary spiral dangerously high[10].

Fiscal austerity has already pushed many countries in Europe further into recession and has become selfdefeating as far as fiscal consolidation is concerned. This particularly holds for the debt-ridden euro area economies, including Greece and Portugal, which have already received EU-Iinternational Monetary Fund bailout packages, and Italy and Spain, which saw the costs of public financing soar in 2011.

Other euro area countries have also fallen back into recession, following fiscal cut over the past two years. Low growth and high unemployment are at the heart of the region's problems. Given that the euro area economies are mostly trading with each other, weak demand in one country also creates significant negative spillover effects[10].

At present, the biggest danger for the euro area is posed by the situation in Italy and Spain as the size of their debts would likely challenge the region's helping funds. 
The main fear is that Spain will slide into a downward spiral of austerity and recession, which will drive up its borrowing costs, leading to increased market turmoil and eventually require a bailout - with insufficient funds available for Italy. Such a scenario would likely involve renewed speculation about a breakup of the euro area, further unsettling financial markets and triggering a sharp downturn in global economic activity.

\section{ACKNOWLEDGEMENTS}

This paper is a result of research made for my $\mathrm{Ph} . \mathrm{D}$. thesis and will be included in my thesis "Management of Business Risk in the context of firms' globalization and internationalization".

\section{REFERENCES}

[1] Paun C., B; (2009). Managing Business Risk, Ed. UNIVERSITARA, ISBN 978-973-749-611-9, Bucharest

[2] Brezeai(Marcu) 1., B.; Ph.D. (2011). Marketing Management In The Frame of Change, Business Globalisation and Firms' Internationalization, Sibiu,Ph.D. Thesis

Preda C.;Racheru I. \&Manea O. (2008). BRIC-Emerging economies, 22 Magazine, The Group for Social Dialog, Bucharest

[3] Bonciu F. (2009). Global Economy, ISBN 9789737497260, Ed. UNIVERSITARA,Bucharest

[4] Albu C. (January 2012). The Institute for Global Economy, World Bank-Perspectives regarding the evolution of global economy and international commerce-2012, from: http://www.iem.ro/, Accessed on : 2012-08-08,Bucharest

[5] Circhelan A.; (26 of June 2012). http://www.zf.ro/businessinternational, Financial Paper, The world economy has entered a vicious circle where one difficult situation inflicts on saving the other;Accessed on: 2012-08-08

[6] Emanuelle Roman,Ernest \& Young, 2012, from: http://www.ey.com/GL/en/Issues/Business-environment, Accessed on: 2012-08-08

[7] Sisea C. (September 7,2012).Leading in European economic growth .Does it matter to romanians?; http://www.ziare.com/economie/crestere-economica/printrefruntasi-la-crestere-economica-in-europa-conteaza-pentruromani-1188603,Ziare.com; Accesed on 2012-20-09

[8] World Economic Situation and Prospects 2012( United Nations publication, Sales No. E 12 II C2) released in January 2012, http://w.w.w.un.org/esa/policy/wess/wesp.html; Accessed on 2012-11-08

[9] http://www.bnro.ro/Buletinul-lunar-BCE, Romanian National Bank, July 2012, Monthly Buletin, Accessed on: 2012-08-10 Bucharest 